\title{
Local movements and translocation experiments of resident and migratory birds in southern Veracruz, Mexico
}

\author{
MARIO A. RAMOS and JOHN H. RAPPOLE
}

\section{Summary}

A total of 114 individuals of 17 resident and 10 migrant species captured at a rainforest study site in the Tuxtla Mountains of southern Veracruz, Mexico, were displaced to a second rainforest site $2.5 \mathrm{~km}$ distant. Return rates to point of capture were high for both groups ( $73 \%$ for resident species versus $74 \%$ for migrants). These comparable rates, when considered with evidence that residents can accumulate large fat reserves, indicate that resident species possess key adaptations necessary for migratory movement.

Un total de 114 individuos pertenecientes a 17 especies residentes y 10 migradoras capturados en un enclave de selva húmeda en las montañas de Tuxtla al sur de Veracruz, México, fueron trasladados a un segundo enclave de selva húmeda situado a $2.5 \mathrm{~km}$ de distancia. Las tasas de retorno al punto de captura fueron altas para los dos grupos (73\% para las especies residentes y $74 \%$ para las migradoras). Teniendo en cuenta que los residentes pueden acumular grandes reservas de grasa, la similitud de estos resultados indica que estas especies poseen las adaptaciones necesarias para el movimiento migratorio.

\section{Introduction}

Migratory birds are often treated as a separate class of species from residents based on their possession of unique abilities. For instance, migrants have special physiological capacities in that they are able to enter a hyperphagic state, laying down large fat reserves prior to and during migratory journeys (King 1972, Berthold 1975). Berthold (1988) and his co-workers have documented a component genetically programmed to the duration of this migratory state. Emlen (1975) found evidence in Indigo Buntings Passerina cyanea of an evidently innate ability to determine migratory direction based on night-time star patterns. Also, migrants have remarkable homing abilities in that they are able to move from point to point and return over considerable distances (Nickell 1968).

A critical capacity in migrants that has not been examined for many resident species is the ability to home to point of origin. In this paper we test the relative short-distance homing abilities of individuals of both migrant and resident species living in rainforest habitat of southern Veracruz, Mexico. 


\section{Study area}

The Tuxtla Mountains of southern Veracruz compose a region of rough volcanic terrain covering approximately $4,200 \mathrm{~km}^{2}$ along the coast of the Gulf of Mexico, $90 \mathrm{~km}$ south-east of Veracruz City at around $18^{\circ} 40^{\prime} \mathrm{N} 95^{\circ} 40^{\prime} \mathrm{W}$. Elevations range from sea level to over $1,700 \mathrm{~m}$. Details of vegetation, rainfall, temperature and topography can be found in Andrle (1964).

Our six study sites were located in and around the Biology Station "Los Tuxtlas" of the University of Mexico. Elevation of the study sites ranged from near sea level to $250 \mathrm{~m}$. A small mountain, Cerro Balzapote (elevation $211 \mathrm{~m}$ ), separated the two main study sites, which were located roughly $3 \mathrm{~km}$ apart (Figure 1). Vegetation on these two sites (Sites 1 and 2, Figure 1) was rainforest with a canopy of $30-35 \mathrm{~m}$, described as "selva alta perenifolia" by Pennington and Sarukhan (1968). In addition to the little mountain, Sites 1 and 2 were separated by a mixture of forest and pasture crossed by the Catemaco-Balzapote road (Figure 1 ).

\section{Materials and methods}

Birds were mist-netted at one or more of the six sites from August 1973 to May 1974, and from August 1974 to May 1975. Details of the netting procedures can be found in Rappole and Warner (1980) and Ramos $(1983,1988)$. Total net-hours exceeded 96,000 . Netting was done at all six sites, but was concentrated at a

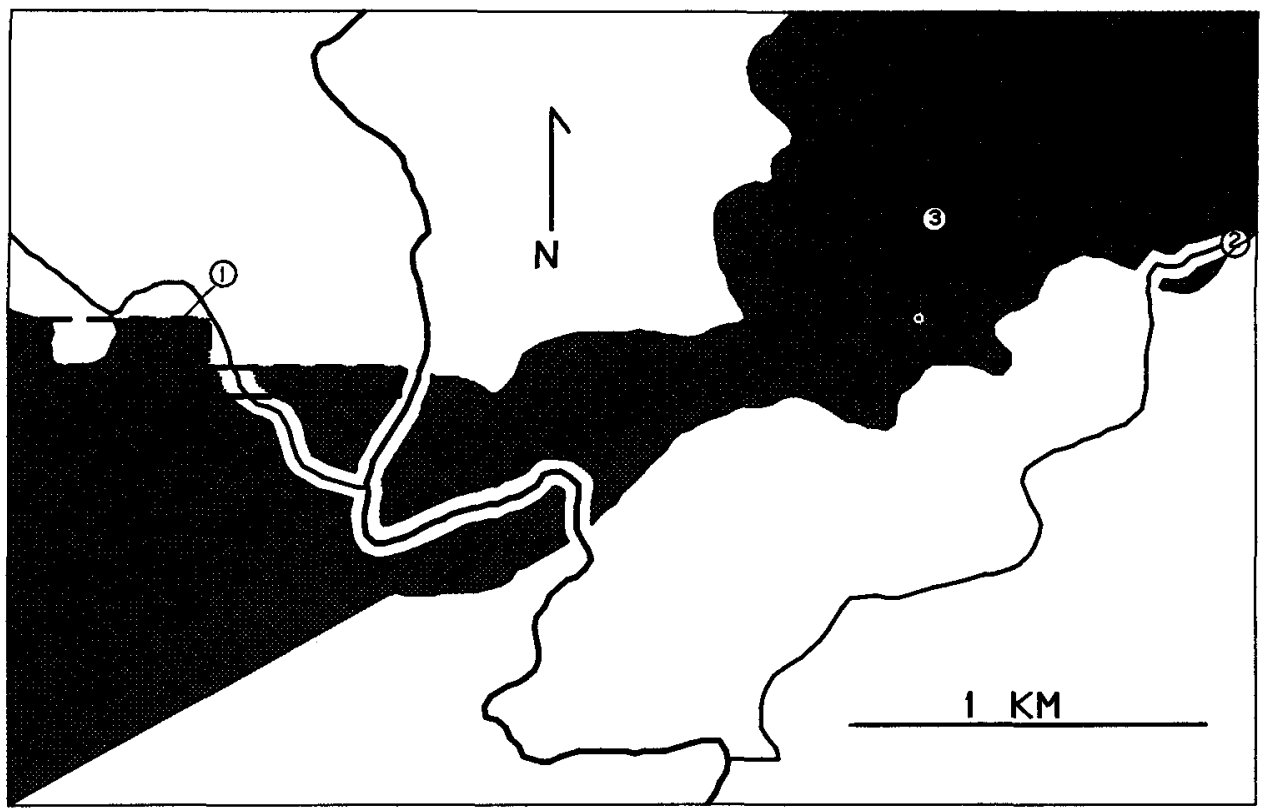

Figure 1. Map of the study area showing the relative location of the capture locality (1), the release point (2), and Cerro Balzapote (3). Roads are shown as a dark line. The study area at (1) is outlined with dashed lines. Forested areas are shaded while open areas are blank. 
study site located in the grounds of the Biology Station (Site 1), $2 \mathrm{~km}$ westsouth-west of the surveyor's marker at the top of Cerro Balzapote, and at Site $2,0.8 \mathrm{~km}$ east-south-east of the marker. Many of the birds captured at Site 1 were transported for banding and release at Site 2. These birds form the basis for the comparisons made in this paper.

\section{Results}

Individuals of 17 resident species and 10 migrant species were involved in the homing experiment. For the 17 resident species, 56 individuals were displaced, $41(73 \%)$ of which, representing 13 species, homed to their point of origin (Table 1). For the 10 migrant species, 58 individuals were displaced, of which 43 $(74 \%)$, representing eight species, homed to their point of origin (Table 2 ). A chi-squared test of these values shows no significant difference between migrant and resident homing rates.

\section{Discussion}

Our data indicate that both migrant and resident species have an innate ability to home to point of origin when displaced. The distance over which these birds homed was not great $(2.5 \mathrm{~km})$. However, three factors indicate that the phenomenon is of considerable importance.

First, the birds homed over a significant geographical impediment, namely Cerro Balzapote. The capture site (Site 1 ) was located west of this hill at elevations of $100-250 \mathrm{~m}$. The release site (Site 2) was located east of the cerro at elevations of 50-100 $\mathrm{m}$. In between, the cerro rises to over $200 \mathrm{~m}$.

Table 1. Total individuals captured and released (Banded), recaptured (Recapt.), displaced (Displ.), homed after to point of origin after displacement (Homed), or remained at point of displacement (Stayed) for 17 resident species

\begin{tabular}{lrrrrr}
\hline Species & Banded & Recapt. & Displ. & Homed & Stayed \\
\hline Campylopterus hemileucurus Violet Sabrewing & 106 & 9 & 1 & 1 & 0 \\
Xenops minutus Plain Xenops & 21 & 9 & 1 & 0 & 1 \\
Dendrocincla anabatina Tawny-winged Creeper & 30 & 16 & 5 & 5 & 0 \\
Sittasomus griseicapillus Olivaceous Woodcreeper & 20 & 7 & 4 & 3 & 1 \\
Glyphorhinchus spiurus Wedge-billed Woodcreeper & 24 & 8 & 1 & 0 & 1 \\
Mionectes oleagineus Ochre-bellied Flycatcher & 123 & 46 & 11 & 10 & 1 \\
Platyrinchus mystaceus White-throated Spadebill & 85 & 23 & 4 & 3 & 1 \\
Myiobius sulphureipygius Sulphur-rumped Flycatcher & 42 & 20 & 2 & 1 & 1 \\
Attila spadiceus Bright-rumped Attila & 33 & 10 & 2 & 2 & 0 \\
Thryothorus maculipectus Spot-breasted Wren & 70 & 28 & 3 & 3 & 0 \\
Henicorhina leucosticta White-breasted Wood-wren & 55 & 15 & 1 & 0 & 1 \\
Turdus grayi Clay-coloured Robin & 22 & 2 & 1 & 1 & 0 \\
Hylophilus ochraceiceps Tawny-crowned Greenlet & 100 & 45 & 3 & 1 & 2 \\
Eucometis penicillata Grey-headed Tanager & 67 & 20 & 9 & 7 & 2 \\
Habia rubica Red-crowned Ant-tanager & 107 & 39 & 2 & 1 & 1 \\
Habia fuscicauda Red-throated Ant-tanager & 139 & 35 & 5 & 3 & 2 \\
Cyanocompsa cyanoides Blue-black Grosbeak & 27 & 3 & $\mathbf{1}$ & $\mathbf{0}$ & $\mathbf{1}$ \\
TOTAL & 1,071 & 335 & 56 & 41 & $\mathbf{1 5}$ \\
\hline
\end{tabular}


Table 2. Total individuals captured and released (Banded), recaptured (Recapt.), displaced (Displ.), homed after to point of origin after displacement (Homed), or remained at point of displacement (Stayed) for 10 migrant species

\begin{tabular}{lrrrrr}
\hline Species & Banded & Recapt. & Displ. & Homed & Stayed \\
\hline Empidonax flaviventris Yellow-bellied Flycatcher & 28 & 10 & 2 & $\mathbf{1}$ & 1 \\
Catharus mustelinus Wood Thrush & 309 & 82 & 23 & 18 & 5 \\
Vireo griseus White-eyed Vireo & 44 & 10 & $\mathbf{1}$ & $\mathbf{1}$ & 0 \\
Mniotilta varia Black-and-white Warbler & 63 & 23 & $\mathbf{1}$ & 0 & 1 \\
Helmitheros vermizorus Worm-eating Warbler & 51 & 16 & $\mathbf{1}$ & 0 & 1 \\
Seiurus aurocapillus Ovenbird & 20 & 9 & 2 & 2 & 0 \\
Seiurus motacilla Louisiana Waterthrush & 8 & 4 & $\mathbf{2}$ & $\mathbf{2}$ & 0 \\
Oporornis formosus Kentucky Warbler & 182 & $\mathbf{2 7}$ & $\mathbf{1 1}$ & 7 & 4 \\
Wilsonia citrina Hooded Warbler & 223 & 56 & $\mathbf{1 4}$ & $\mathbf{1 1}$ & 3 \\
Wilsonia pusilla Wilson's Warbler & 74 & 13 & 1 & 1 & 0 \\
TOTAL & 1,002 & 250 & 58 & 43 & $\mathbf{1 5}$ \\
\hline
\end{tabular}

Second, a mosaic of pasture, forest, second growth and an opening for a road $30 \mathrm{~m}$ wide lies between the capture and release sites. Birds attempting to return to point of capture must cross areas of unsuitable habitat.

Third, despite 96,000 net-hours accumulated at these sites during which over 4, ooo birds were captured, banded and released, no birds released at point of capture at one site were ever captured at the other site, indicating that normal movement of birds between these sites is, at best, a very rare event.

We believe that our homing data complement other data indicating that resident birds possess several of the "special" adaptations generally attributed to migrants as a class (Keast 1980). These findings provide further evidence that the differences between the physiological and behavioural capabilities for movement between migrants and residents are not as great as has generally been assumed (Rappole and Warner 1980, Ramos 1983, Rappole and Tipton 1992, Levey and Stiles this issue). For instance, researchers have found that many species of residents have the capacity to lay down fat reserves in a fashion similar to migrants (Beebe 1947, McClure 1974, Rappole and Warner 1980). Furthermore, the "residence" status of some resident species is open to question based on observation of local/regional movements documented by mist-netting (Ramos 1988, Levey and Stiles this issue) and radio-tracking (Powell and Bjork this issue). An additional indication of the similarity in capabilities between these groups is that temperate-tropical migrant and tropical resident populations exist for over 150 species of birds (Rappole et al. 1983, Rappole et al. in press) including species like the White-eyed Vireo Vireo griseus, White-tailed Hawk Buteo albicaudatus and Laughing Gull Larus atricilla.

Earlier studies have focused on the evident differences between migratory and resident species in the tropics. Keast (1980), for instance, stated that there are basic characteristics separating these groups, e.g. the capacity of migrants to live at different latitudes, to change habitats seasonally, to compete with a different set of species, to have physiological adaptations for migration, and to lay large clutches. However, Ramos (1988), Levey and Stiles (this issue), and Powell and Bjork (this issue) have documented that tropical residents do change habitats seasonally. Beebe (1947), Grant (1965), McClure (1974), and Rappole and Warner (1980) have documented the ability of tropical residents to store fat 
and, in this paper, we document the fact that migrants and residents have comparable short-distance homing abilities.

The rapid development of migratory populations of evidently resident tropical species is further indication of the similar capacities between the two categories. An example of this phenomenon is provided by the Cattle Egret Bubulcus ibis. This resident of the Old World tropics arrived in South America in the late nineteenth century, spreading gradually northward until it reached the temperate zone in the early 1950s (Peterson 1960). Since then, this species has developed populations that perform regular, long-distance migrations between the north temperate zone and the tropics (Bull 1974).

We hypothesize that resident species have an innate capacity for development of migratory movement. When environmental circumstances favour movement by individuals of these species, as is perhaps probably the case for many dispersing individuals, they will show physiological and behavioural responses similar to those of migratory species. This hypothesis can be tested using the classic laboratory experiments on residents similar to those developed by Farner and King for migrant White-crowned Sparrows Zonotrichia albicollis (King 1972), along with a series of displacement experiments for residents at increasingly larger distances from point of capture.

Mayr (1963), based on observation of evident differentiation between populations separated only by rivers, stated that tropical resident birds in general have limited dispersal abilities. However, this assumption has received very little critical examination, and the studies that have been done have documented much greater movement capabilities than had previously been thought (Wunderle 1981a,b, Powell and Bjork this issue). The existence of seasonal or temporal mobility of migrant and resident populations presents additional challenges for the conservation of these species. Any planning of parks and reserves must take into account the particular movement patterns of individual species.

\section{Acknowledgements}

We thank Dwain Warner, Isabel Castillo de Ramos, Bonnie Rappole, Chris Barkan, Richard J. Oehlenschlager, Bruce Fall and Angel Toto for field assistance. Personnel from the Mexican government and the University of Mexico Biology Station were helpful with permits and logistics. We thank the Welder Wildlife Foundation, the Chapman Fund, the Dayton Fund, American Museum of Natural History, INIREB and the Sigerfoos Fellowship programme from the University of Minnesota for providing financial support for the project.

\section{References}

Andrle, R. F. (1964) A biogeographical investigation of the Sierra de Tuxtla in Veracruz, Mexico. Baton Rouge: Louisiana State University (Ph.D. thesis).

Beebe, W. (1947) Avian migration at Rancho Grande in north-central Venezuela. Zoologica 32: 153-168.

Berthold, P. (1975) Migration: control and metabolic physiology. Pp.77-128 in D. S. Farner and J. R. King, eds. Avian biology, 5. New York: Academic Press. 
Berthold, P. (1988) The control of migration in European warblers. Proc. Internatn. Orn. Congr. 19: 215-249.

Bull, J. (1974) Birds of New York State. New York: Doubleday, Garden City.

Emlen, S. T. (1975) Migration: orientation and navigation. Pp.129-219 in D. S. Farner and J. R. King, eds. Avian biology, 5. New York: Academic Press.

Grant, P. (1965) The fat conditions of some island birds. Ibis 107: 350-356.

Keast, A. (1980) Migratory Parulidae: what can species co-occurrence in the north reveal about ecological plasticity and wintering patterns? Pp.457-476 in A. Keast and E. S. Morton, eds. Migrant birds in the Neotropics. Washington, D.C.: Smithsonian Institution Press.

King, J. R. (1972) Adaptive periodic fat storage by birds. Proc. Internatn. Orn. Congr. 15: 200-217.

Mayr, E. (1963) Animal species and evolution. Cambridge, MA: Harvard University Press.

McClure, H. E. (1974) Migration and survival of the birds of Asia. Bangkok: U.S. Army Med. Component SEATO Medical Project.

Nickell, W. P. (1968) Return of northern migrants to tropical winter quarters and banded birds recovered in the United States. Bird-Banding 39: 107-116.

Pennington, T. D. and Sarukhan, J. (1968) Arboles tropicales de México. Mexico, D.F.: Instituto Nacional de Investigaciones Forestales.

Peterson, R. T. (1960) A field guide to the birds of Texas. Boston: Houghton-Mifflin.

Ramos, M. A. (1983) Seasonal movements of bird populations at a Neotropical study site in southern Veracruz, Mexico. Minneapolis: University of Minnesota (Ph.D. thesis).

Ramos, M. A. (1988) Eco-evolutionary aspects of bird movements in the northern Neotropical region. Proc. Internatn. Orn. Congr. 19: 251-293.

Rappole, J. H. and Tipton, A. R. (1992) Evolution of migration. Ornitología Neotropical 3: 45-55.

Rappole, J. H. and Warner, D. W. (1980) Ecological aspects of avian migrant behavior in Veracruz, Mexico. Pp.353-393 in A. Keast and E. S. Morton, eds. Migrant birds in the Neotropics. Washington, D.C.: Smithsonian Institution Press.

Rappole, J. H., Morton, E. S., Lovejoy, T. E. and Ruos, J. R. (1983) Nearctic avian migrants in the Neotropics. Washington, D.C.: U.S. Department of the Interior, Fish and Wildlife Service.

Rappole, J. H., Ramos O., M. A., Winker, K., Oehlenschlager, R. J. and Warner, D. W. (in press) Nearctic avian migrants of the Tuxtla Mountains and neighboring lowlands. In R. Dirzo and R. Vogt, eds. Natural history of the Tuxtla Mountains of southern Veracruz.

Wunderle, J. M. (1981a) An analysis of a morph-ratio cline in the Bananaquit (Coereba flaveola) on Grenada, West Indies. Evolution 35: 333-344.

Wunderle, J. M. (1981b) Movement of adult and juvenile bananaquits within a morphratio cline. Auk 98: 571-577.

MARIO A. RAMOS

Global Environment Facility, The World Bank, 1818 H Street NW, Washington, D.C. 20433, U.S.A.*

\section{JOHN H. RAPPOLE}

Conservation and Research Center, National Zoological Park, Smithsonian Institution, Front Royal, VA 2263o, U.S.A.

*Any opinions expressed in this paper are those of the authors and do not necessarily represent the views of the World Bank. 